Dino Abazović

\section{Bosanskohercegovački muslimani između sekularizacije i desekularizacije}

Zagreb - Sarajevo: Synopsis, 2012, 199 str.

DOI: 10.11567/met.29.3.6

Dino Abazović, profesor na Fakultetu političkih nauka u Sarajevu, u većini svojih radova bavi se sociologijom religije te suvremenim političkim procesima i stanjem u Bosni i Hercegovini. U svojoj posljednjoj knjizi Bosanskohercegovački muslimani između sekularizacije $i$ desekularizacije nastojao je na temelju empirijskog istraživanja dati prikaz bosanskohercegovačkih muslimana, njihovih religijskih stavova, vrijednosti i praksi u specifičnim tranzicijskim okolnostima u kojima žive, ali i u svjetlu procesa sekularizacije, odnosno desekularizacije, kao središnje teme suvremene sociologije religije. Knjiga uz uvodni dio sadržava četiri dijela: Sekularizacijske teorije i društva u tranziciji, Bosna i Hercegovina: promišljanje relacija konfesionalni - etnički - nacionalni identiteti, Kvantitativna i kvalitativna analiza prikupljenih podataka i Zaključna razmatranja. U uvodnom dijelu autor ističe da pod pojmom bosanskohercegovačkih muslimana smatra »sljedbenike islama koji su porijeklom - porodičnim, kulturnim, tradicijskim, jezičkim i etničkim - vezani za Bosnu i Hercegovinu« (str. 14). Suvremeni teoretičari ističu kako je danas na snazi proces koji se može pratiti diljem svijeta (pa čak i na Zapadu), a odnosi se na zamah oživljavanja religija, koji se $\mathrm{u}$ literaturi naziva resurgence of religion, desekularizacija, resakralizacija, deprivatizacija religije, religijska ob- nova itd. U nastojanju da prikaže »tko su danas bosanskohercegovački muslimani« (str. 17) Abazović kontekstualizira svoje istraživanje opisujući specifični povijesni, kulturni i politički kontekst u kojemu žive, ali i uvidom u najvažniju dilemu suvremene sociologije religije, pitanje sekularizacije i desekularizacije.

Prvi dio knjige »Sekularizacijske teorije i društva « $u$ tranziciji podijeljen je na tri poglavlja (Sociološko određenje sekularizacije, Implikacije procesa sekularizacije i desekularizacije u suvremenom svijetu i Postsocijalistička društva u tranziciji: procesi /de/sekulariziranja). Autor u prva dva daje sažeti ali sveobuhvatni pregled debate o sekularizaciji, koju smatra krajnje kompleksnim fenomenom koji se često pojednostavljuje. Slaže se s Malcomom Hamiltonom, koji smatra da je korijen prihvaćanja ili neprihvaćanja teorije sekularizacije $\mathrm{u}$ načinu definiranja religije. Teoretičari koji religiju definiraju prema funkciji (lumanovski rečeno, prema preformansama, odnosno primjeni religije na druge društvene sustave) skloni su odbaciti teoriju sekularizacije, a oni koji je definiraju prema sadržaju, odnosno njezinoj biti (što Luhmann naziva funkcijom ili čistom religijskom komunikacijom o transcendentnom i aspektima koje religijske institucije prisvajaju), skloni su je prihvatiti. No teorija sekularizacije kao »mit koji su sociolozi sakralizirali« (Glasner, citat na str. 22) doživljava sve veće kritike, naročito nakon razvoja teorije racionalnog izbora religije i religijske pluralizacije. Premisu da opadanje važnosti religije slijedi iz razvoja moderniteta i procesa koji ga karakteriziraju (diferencijacije društvene strukture, racionaliza- 
cije, birokratizacije i nestanka zajednice) snažno opovrgavaju brojni teoretičari. Istodobno se javljaju i autori koji ističu da sekularno i religijsko nisu suprotnosti, nego postoje na različitim razinama (Asad), da religija može zadržati svoju važnost $u$ području individualnoga te je gubiti u društvu kao cjelini (Tschannen), odnosno da je ona multidimenzionalan fenomen (Dobbelaere, Casanova i Beyer). Abazović ističe kako sekularizaciju stoga treba promatrati na svim razinama (društvo/institucije/pojedinac) i imati $u$ vidu da je ona »opisna (deskriptivna), a nikako normativna, odnosno predviđajuća hipoteza« (str. 29).

Osnovni principi demokratskih društava temelje se na zahtjevu da se $\mathrm{u}$ javnim istupanjima distancira od religijske pozadine (laicitet) i na razlikovanju društvenih sfera, pri čemu je religijska tek jedna u nizu, isprepletena s drugima (sekularizacija). S druge strane, globalizacijski fenomeni koji izazivaju egzistencijalnu nesigurnost i strepnju pred budućnošću potiču religijske zajednice na reakciju, pa religija postaje jedan od najvažnijih izvora za konstrukciju identiteta. I Europska unija zauzima stav koji je iznijela ekspertna grupa Reflection Group on the Spiritual and Cultural Dimensions of Europe da se europska kultura temelji na nacionalnim i religijskim tradicijama koje imaju biti kohezivni čimbenik nove Europe. Postoji dakle osjetljiva granica koja »brani« javnu sferu od zloupotrebe religijskih institucija u različite svrhe (npr. opravdavanja etničkih sukoba).

U zadnjem poglavlju prvog dijela knjige Abazović ukratko opisuje postsocijalističku tranziciju bosanskohercegovačkog društva. Nakon raz- doblja socijalizma, u kojemu se religija izrazito negativno percipirala i stigmatizirala, odnosno umjetno se provodila sekularizacija (str. 41), jača nacionalizam, koji religiju transformira u zaštitnicu novostvorene »oslobođene «nacije i politizira je kako bi služila legitimaciji novog poretka.

Drugi dio knjige »Bosna i Hercegovina: promišljanje relacija konfesionalni - etnički - nacionalni identiteti« daje povijesni pregled razvoja Bosne i Hercegovine s posebnim osvrtom na razvoj religijske zajednice Bošnjaka muslimana. Taj je dio podijeljen na četiri poglavlja: Kratak osvrt na historijska dešavanja, Islamska zajednica kao vjerska institucija muslimana, Konfesija i etnicitet: o povijesno-sociopolitički determiniranoj neodvojivosti i Postdaytonska Bosna i Hercegovina: »problemi« s kolektivitetima. Prema nekim autorima, u predosmanlijskoj Bosni nije se razvilo duboko ukorijenjeno religijsko usmjerenje, nego je postojao svojevrsni religijski pluralizam (str. 51), zbog čega je veliki dio stanovništva isprva dobrovoljno prihvaćao islam. Velike promjene nastupaju dolaskom Austro-Ugarske Monarhije na prostor Bosne i Hercegovine jer »islam prestaje biti državnom religijom « (str. 63), a muslimansko nezadovoljstvo austrougarskom administracijom i njezinim miješanjem u vjersku domenu jača. Prvim organiziranim djelovanjem muslimansko stanovništvo u Pokretu za vakufsko-mearifsku autonomiju 1909. uspjelo je osigurati samostalnost $u$ vođenju vjerskih, vakufskih i obrazovnih poslova. Za Kraljevine Srba, Hrvata i Slovenaca islamska zajednica bila je gurnuta u stranu jer je interes političkih snaga bio usmjeren na odnose Srba i Hrvata 
te moguće negativne uloge Katoličke i Pravoslavne crkve na razvoj unitarnih jugoslavenskih ideja. Za Kraljevine Jugoslavije kralj Aleksandar Karađorđević zadao je Vidovdanskim ustavom 1929. posebno jak udarac islamskoj vjerskoj zajednici ukidajući joj autonomiju postignutu 1909. Nakon raspada Šestosiječanjske diktature Jugoslavenska muslimanska organizacija uspijeva vratiti izgubljena prava, koja zadržava i pod režimom NDH tijekom Drugoga svjetskog rata. Poslije rata Bosna i Hercegovina ulazi u sastav SFRJ, gdje su se sve vjerske zajednice, pa tako i islamska, percipirale kao negativna pojava. No muslimanska zajednica razlikovala se od ostalih time što njeni pripadnici nisu razvili nacionalni identitet, nisu imali formalne vjerske organizacije koje su prizivale povijesne momente etnonacionalizma u kolektivnu memoriju. Stoga okosnica nacionalne identifikacije postaje religija te se pojam Musliman rabi kao odrednica nacionalnog opredjeljenja (od 1971., a do tada su se izjašnjavali kao musliman - nacionalno neopredijeljen, Srbin, Hrvat ili Jugoslaven). Tek se 1993. odrednica Bošnjak uvodi kao oznaka nacionalnog imena. Početkom devedesetih godina prošloga stoljeća, kad jačaju nacionalne nesnošljivosti nakon raspada Jugoslavije (potpomognute buđenjem nacionalizma), religija bosanskohercegovačkih muslimana postaje još značajniji čimbenik nacionalne samoidentifikacije. Novostvorene političke strukture nalaze legitimaciju u religiji »zaogrnutoj nacionalnim plaštom« (Ćimić, citat na str. 92), pa se religija i politika isprepleću, rješenja političkih pitanja traže se u polju religioznoga i obratno.
Treći dio knjige donosi kvantitativnu i kvalitativnu analizu podataka prikupljenih $\mathrm{u}$ anketi provedenoj 2007. na reprezentativnom uzor$\mathrm{ku}$ od petsto osoba. Upitnik se sastojao od 32 pitanja s više od 150 varijabli podijeljenih $\mathrm{u}$ deset cjelina, koje čine i poglavlja tog dijela knjige: Nacionalna i konfesionalna samoidentifikacija, Osobna religioznost, Religijska praksa, Doživljaj Božje prisutnosti, Religijska vjerovanja, Životna važnost religije, Autoritarizam, Tradicionalizam, Etnocentrizam (socijalna distanca i zatvaranje) i Nacionalizam i odnos prema Zapadu. Populacija bosanskohercegovačkih muslimana živi u izrazito lošim ekonomskim uvjetima (oko $40 \%$ ispitanika ima završenu ili nezavršenu osnovnu školu, zaposlenih je $20 \%$, a obiteljska mjesečna primanja u razini prosječnih osobnih primanja ima manje od $10 \%$ ispitanika, str. 167). U smislu nacionalne samoidentifikacije najveći dio ispitanika opredijelio se za opciju Musliman (55,7\%), a zatim za opciju Bošnjak (22,7\%). Abazović smatra da je razlog tomu duga praksa samoidentifikacije tim nazivom i odbijanja renominacije do koje je došlo u vrijeme ratnih sukoba. Također ističe kako (osim skora autoritarnosti i odnosa prema $\mathrm{Za}-$ padu) nema statistički značajne razlike među ispitanicima ovisno o njihovoj nacionalnoj samoidentifikaciji. Da pripada islamskoj religijskoj zajednici, izjasnilo se $84,6 \%$ ispitanika. S tim u korelaciji $82,6 \%$ ispitanika samoidentificiralo se kao religiozno. U pogledu religijske prakse upitnik je bio konstruiran prema "pet temelja islama«, a rezultati pokazuju da postoji visoki stupanj "poklapanja konfesionalnosti s religioznošću« (str. 131), 
ali uz određena (ponekad i značajna) odstupanja. Problem analize religijske prakse, ističe autor, jest u tome što je ona kod pojedinaca često motivirana najrazličitijim uzrocima (tradicionalnim, društvenim, praktičnim i religioznim). Prema stupnju osobne privrženosti religiji Abazović je većinu ispitanika svrstao $\mathrm{u}$ »obične $\mathrm{i}$ »uvjerene« vjernike (prema Cvitkovićevoj tipologiji, str. 133). Da vjeruje u Alaha, izjasnilo se $92,6 \%$ ispitanika, što je više od rezultata religiozne samoidentifikacije, što nam govori da postoje određeni oblici duhovnosti koji nisu prepoznati kao religioznost. Povjerenje u religijsku zajednicu prisutno je kod ispitanika, ali nije jako izraženo. Smatraju da vjerska zajednica ima pozitivan učinak u sferi duhovnog i osobnog života, a negativan u sferi širega društvenoga konteksta. Da im je religija jako važna u životu, ističe $53,1 \%$ ispitanika, a istovremeno pod utjecajem suživota s drugim vjerskim zajednicama i svakodnevnog života postoji različit stupanj suglasnosti s određenim pravilima ponašanja koja proizlaze iz religijskih vjerovanja (o hrani, piću i načinu odijevanja). Većina ispitanika smatra da religijski vođe ne bi trebali imati utjecaja na vlast i politička zbivanja. U pogledu autoritarnosti i tradicionalnosti postoji tendencija porasta, koju autor povezuje s nepovoljnom političko-gospodarskom situacijom, odnosno takvi se stavovi javljaju »po potrebi ili spletu okolnosti« (str. 151). Skala etničke distance koja je upotrijebljena za mjerenje etnocentrizma očekivano pokazuje da je socijalna distanca prema drugim narodima veća u području privatnog i obiteljskog života, međutim duga tradicija multietničkog života ipak utječe na to da se, iako se »teži održavanju unimodalnosti životnih sredina «, »ipak radi o nekoj vrsti prelaznog modela koji bi bio između 'života jednih pored drugih' i 'života jednih sa drugima' « (str. 156). U analizi nacionalizma autor dolazi do zaključka da je prisutan latentni nacionalizam koji se očituje u nepovjerenju prema pripadnicima drugih naroda i favoriziranju pripadnika svoje grupe, što je i očekivana posljedica ratnog sukoba. Nepovjerenje prema Zapadu kod ispitanika također je, pretpostavlja Abazović, posljedica ratnih sukoba i (ne)djelovanja međunarodne zajednice. Ispitanici koji su se izjasnili kao Muslimani u smislu nacionalne pripadnosti značajno su zatvoreniji prema Zapadu od ostalih.

U zadnjem dijelu knjige »Zaključna razmatranja « autor sažeto iznosi podatke dobivene empirijskim istraživanjem. Populacija bosanskohercegovačkih muslimana pokazuje »visok stupanj konfesionalne samoidentifikacije i deklarativne afilijacije religijskoj instituciji« (str. 168), visok stupanj vezanosti uz religiju i prosječno povjerenje u religijsku zajednicu, čija je uloga u sferi privatnoga percipirana pozitivno, a u sferi društvene problematike negativno. Sukladno tomu eventualno jačanje uloge religije vide u području obiteljskog života i obrazovanja, a nikako u području javnog života (politika i mediji). I socijalna distanca veća je u području privatnog i obiteljskog života, a nacionalizam je prisutan kao tendencija favoriziranja homogenosti životnog okružja. Abazović zaključuje kako bosanskohercegovački muslimani žive između sekularizacije i desekularizacije u smislu da procesi tih dvaju fenomena »nemaju iste učinke na nivou društvenog 
i javnog života muslimana ni na nivou osobnog religijskog života pojedinaca niti su im iste manifestacije « (str. 172), odnosno sekularizacijski su procesi manje izraženi u prostoru javnoga (što ne usporava procese diferencijacije društvene strukture), a potaknuti su događanjima vezanima uz raspad socijalizma i stvaranje novih nacionalnih država, koje svoju legitimaci- ju traže u polju religijskoga. Isto tako, na području osobnoga religijskog života postoji preklapanje konfesionalnosti i religioznosti, izraženija konfesionalna pripadnost pretpostavlja jače očitovanje religije, ali ne i dosljednost vjerničkog života.

Nikolina Hazdovac Bajić

Institut društvenih znanosti »Ivo Pilar«, Dubrovnik
Anđelko Milardović

\section{Stranac i društvo: fenomenologija stranca i ksenofobija}

Zagreb: Pan Liber, 2013, 248 str.

DOI: $10.11567 /$ met.29.3.7

U izdanju Pan Libera 2013. godine objavljena je knjiga politologa Anđelka Milardovića Stranac i društvo: fenomenologija stranca $i$ ksenofobije. Najnovija Milardovićeva knjiga nastala je kao dio znanstvenoga projekta »Interkulturni pristup etničkoj različitosti i identitet: Hrvatska - Europa « koji se provodio $u$ Institutu za migracije i narodnosti od 2008. do 2013. Prema autorovim riječima, knjiga je duboko motivirana osobnim i širim obiteljskim iskustvom života izvan domovine, životom »iskorijenjenog čovjeka« - stranca te željom da se tom iskustvu dade znanstveni okvir.

Knjiga Stranac i društvo pisana je multidisciplinarno, kombinirajući znanstvene spoznaje sociologije, etike, filozofije, povijesti, prava, antropologije, psihologije, lingvistike i politologije s posebnim fokusom na fenomenologiji stranaca pod utjecajem Alfreda Schütza, Georga Simme- la i čikaške sociološke škole. Fenomen stranca star je koliko i čovjek, odnosno kao društvo, kultura i civilizacija. Kao društveno biće između dviju kultura, stranac ima svoju »sudbinu « od početaka kultura i civilizacija pa sve do postmodernoga globaliziranoga društva.

Autorova je polazišna teza da se $» u$ svim društvima tijekom povijesti civilizacija, uključujući i današnje suvremene civilizacije i društva, odnos prema strancu temeljio na minimalnoj integraciji, isključivanju i neprijateljstvu te racionalnom i iracionalnom strahu« (str. 213). Odnos prema strancu zapravo je odnos prema Drugome, a markeri koji razlikuju Prooga i Drugoga jesu jezik i kultura, što ne znači da stranci ne postoje i unutar istog jezika i iste kulture. Odnos prema Proome temelji se na identitetu, odnosno istovjetnosti, a odnos prema Drugome na razlici, odnosno drugosti.

Knjiga je podijeljena na dva velika poglavlja: »Teorijsko-metodološka pitanja «, koje se sastoji od četiriju analitika: Temeljni pojmovi i teorija, Stranci u povijesti kultura i civilizacija, Slike stranca kao mogućeg Drugog i Slike straha, te »K sociologiji stranca i ksenofobije«, koje obuhvaća pet analiti- 